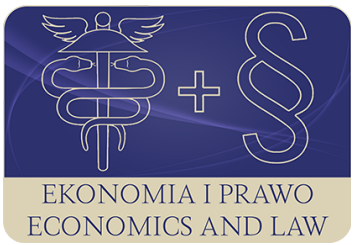

EKONOMIA I PRAWO. ECONOMICS AND LAW

Volume 17, Issue 3, September 2018

p-ISSN 1898-2255, e-ISSN 2392-1625

www.economicsandlaw.pl

ORIGINAL ARTICLE

received 02.01.2018; revised 25.04.2018; accepted 30.09.2018

Citation: Ziętarski, J. (2018). Legal destructive entrepreneurship in the modern economy. Ekonomia $i$

Prawo. Ecomomics and Law, 17(3): 339-350.

doi:10.12775/EiP.2018.025.

\title{
Legal destructive entrepreneurship in the modern economy
}

\author{
JAROSEAW ZIĘTARSKI \\ Gdańsk University of Technology, Faculty of Management and Economics, Department of Economic \\ Analysis and Finance, ul. Traugutta 79, 80-233 Gdańsk, Poland \\ ఐ jaroslaw.zietarski@zie.pg.gda.pl
}

\begin{abstract}
Motivation: Usually examples of activities that have a positive impact on the economy of the state are cited. Destructive entrepreneurship refers to activities that have negative impact on the economy. This phenomenon is relatively new in the literature and does not yet have a precise definition.

Aim: The aim of this article is to attempt a definition of the phenomenon of legal destructive entrepreneurship. The author also analysed the characteristics of legal entrepreneurial behaviour that have a negative impact on the economy of the state.

Results: Based on the different definitions the author proposes to adopt a definition on the basis of which a division into legal and illegal entrepreneurship as well as productive, unproductive and destructive entrepreneurship was made. Author provides comparative analysis of different types of legal destructive entrepreneurship and gives examples of its manifestation under modern economy.
\end{abstract}

Keywords: destructive entrepreneurship; legal destructive entrepreneurship

JEL: Al0; D6; E2; G0; H70; H40

\section{Introduction}

When analysing the economy of different countries it should be stated that one of the factors that draws the attention is the entrepreneurship of its citizens. Diversity of entrepreneurial behaviour is to decide on the state of the economy of the country. Usually examples of activities that (albeit to varying degrees) have a positive impact on the economy of the state are cited. Destructive entre- 
preneurship refers to activities that have negative impact on the economy. This phenomenon is relatively new in the literature and does not yet have a precise definition. The aim of this article is to attempt a definition of the phenomenon of legal destructive entrepreneurship. The author also analysed the characteristics of legal entrepreneurial behaviour that have a negative impact on the economy of the state and pointed to the examples thereof in the modern economy. This publication is theoretical in nature, ordering the available knowledge on destructive entrepreneurship. On the basis of different authors' considerations, a definition of this phenomenon was proposed. In addition, the article shows how to analyse the impact of this kind of behaviour on the size of the Gross Domestic Product, and provides examples referring to the modern economy.

\section{Literature review}

The precursor for defining the term of destructive entrepreneurship is Baumol (1990, p. 894), who put this kind of entrepreneurship alongside productive and unproductive ones. By differentiating between the types of individual behaviour he pointed to their impact on economic growth. Even though there is no direct reference to destructive expressions of entrepreneurship and to methods needed to identify the differences between productive and destructive entrepreneurship, one should pay attention to two terms used to indicate the course of the discussion, i.e.: legal and rent, referring them to the negative impact on the economy.

Legality refers to behaviour consistent with the law. Baumol (1990) refers the term rent to the meaning described in the publication of Schumpeter who described the phenomenon of rent-seeking as an innovative action of an entrepreneurial nature. Various authors have proposed variations of this term from the ground rent to absolute, differential, monopolistic, schumpeterian, ricardian, relational, political, and economic (see Backhaus (1997, pp. 4, 6-10); Begg (1993, p. 316); Brooke (2010, p. 543); Chołaj (1966, p. 212); Czakon (2010); Czyżewski (2010, pp. 316); Czyżewski \& Czyżewski (2015); George (2009); Marks (1959, pp. 328-329); Pareto (1896); Robinson (1948, p. 103); Samuelson (1951, p. 543); Smith (1954, pp. 190-191, 212-213)). The economic rent no longer refers directly to the land but to the factors of production. It equals the surplus income over the alternative remuneration factor (from the manufacturing), which can be obtained in another situation. Sautet (2005, p. 9) proposed the separation from the production factors. In his definition, rent-seeking consists of two types of activities: taking over the benefits from others in a manner consistent with the law and stealing. In this approach, the rent was made synonymous with the benefits. Rent was defined more specifically by A. Krueger (1974, pp. 291-303), who said that rent-seeking is the phenomenon of the pursuit by various entities to obtain material benefits by exerting influence on the economic environment or the legal status. This is still too vague a determination of rent to provide concrete examples of rent-seeking. 
Reflections on the type of entrepreneurship were continued by Murphy (1991, p. 506), who directly divided entrepreneurship into productive and connected with the seeking rents. Such an approach leads to the conclusion that rent-seeking was to be the only kind of entrepreneurship not to be classified as a productive one. However, it still does not explain the differences between the activities of unproductive and destructive entrepreneurship.

Other authors, S. Desai and Z. Acs $(2008$, p. 2), by undertaking studies on destructive entrepreneurship noted that there are no conceptual frameworks which would explain this phenomenon. In their model, S. Desai and Z. Acs $(2008$, p. 3) accepted that destructive entrepreneurship has a negative impact on GDP and similarly negative impact on the rent in consequence of the implementation of this kind of behaviour in production processes. It is worth mentioning a remark of the authors that destructive entrepreneurship is linked, which means that it can create profits (benefits) in one place while reducing them in another. They treat rent-seeking, citing Baumol (1990), as an effect of unproductive activity adding that it is connected with the redistribution of wealth and reduced growth. In their publication they indicate that in the research for the essence of entrepreneurship, there are dilemmas whether it should be formal or informal entrepreneurship, legal or illegal, etc (Desai \& Acs, 2008, p. 8). Unproductive type of entrepreneurship is between productive and destructive types. All of them are related to rents capture.

A. Sauka (2008, pp. 4-5), presents a slightly different view, claiming that the unproductive and destructive actions (as opposed to Baumol's theory) can take the shape of illegal actions and various forms of corruption. While the previous authors allowed illegal acts in reference to capture rent, in the destructive entrepreneurship they looked for behaviours that were consistent with the law. Such an approach requires differentiation of rents due to their compatibility (or incompatibility) with the law.

M. Starnawska (2011, p. 22) defines, as destructive behaviours, those that benefit at the micro level and adversely affect the economic growth. She identified the destructive behaviour directly in line with the illegal entrepreneurship.

Yet another view on this subject was presented Ch.J. Coyne and P.T. Leeson (2004, pp. 236-237). They proposed the division on productive, unproductive and evasive entrepreneurship. They found that unproductive and evasive entrepreneurship result in economic stagnation or regress to the economy. According to them, unproductive entrepreneurship includes the activity on which the entrepreneur has benefits with detriment to the society. Evasive actions were exemplified by them as the expenses related to the resources and efforts undertaken to circumvent the legal system, or to avoid the unproductive activities undertaken by the other entities. According to these authors, both productive and unproductive entrepreneurship are involved in creating losses (deadweight losses) because in both cases the expenses are associated only with the distribution of existing wealth. 
F. Sautet (2005, p. 8), presented the productive, evasive, and socially destructive entrepreneurship. He finds the sources of evasive entrepreneurship in formal institutions whose activities can lead to ignoring of the accepted rules by the entrepreneurs. Functioning systems of rules reduce the value of profits, which would encourage informal activities. On the other hand, he gives the name of socially destructive activity to an involvement in activities such as zero- or negative-sum games, rent-seeking (understood as an activity protected by legislation which imposes costs to the consumers and taxpayers) and theft.

Henrekson $(2007$, p. 5, 7) indicates predatory entrepreneurship as synonymous to destructive and unproductive but does not treat it synonymously with corruption. Douhan and Henrekson (2008), presented the differences between the three types of entrepreneurship. This time, they proposed the division of the three types of entrepreneurship depending on the type of activity undertaken by the entrepreneur i.e. abide by or evade the principles and law.

Taking into consideration the foregoing opinions of various authors in regard to the phenomenon of destructive entrepreneurship it is clear that there is no single coherent definition that would determine the further course of scientific discourse.

\section{Methods}

The research methodology is the method of observation and analysis of cases.

Defining the destructive entrepreneurship requires a number of assumptions. Firstly, in this publication the author made an assumption (according to the original understanding adopted from Baumol (1990)) that the actions undertaken under the legal destructive entrepreneurship will be compatible with the law. Activities contrary to the law will be classified as illegal entrepreneurship. Secondly, the actions taken under the destructive entrepreneurship will be characterised by a net negative impact on the GDP. Thirdly, it must be assumed that these actions will result in benefits in another entity, e.g. in the micro scale or in macro scale in another country i.e. a positive net impact on GDP of another country. In connection with the above assumptions it is possible to adopt the following definition: legal destructive entrepreneurship means a set of activities compliant with applicable law which have a negative net impact on GDP of the country where the situation is considered. Such actions generate benefits at the micro level (regardless of whether they took place in the considered or in another country), or the macro level, in another country.

Legal unproductive entrepreneurship will be a set of activities whose net impact on the GDP of the country is zero (neutral), or close to zero. Similarly to the case of legal destructive entrepreneurship it should be classified as being in accordance with the law, and resulting in benefits in another entity, at the micro scale, or at the macro level in another country. This is illustrated in scheme 1. 
When analyzing scheme 1, one can come to the conclusion that unproductive entrepreneurship can send a warning message for the economy of the country.

Illegal entrepreneurship means a set of illegal activities. Also in this case, they may be of productive, unproductive and destructive character.

The typology of destructive, unproductive and productive entrepreneurship due to its relation to the law is presented in scheme 2 .

Based on the scheme 2. it should be stated that all activities, both legal and illegal, can be considered as productive, unproductive or destructive.

Since the difference in the three categories of the considered legal entrepreneurship is associated with separate impact net on GDP, one must analyse the determinants of GDP.

According to the expenditures approach of calculating GDP, it is the result of the sum of household consumption, investment, government spending, and net exports.

The income approach of calculating GDP adds up three categories of income: disposable income of households, income factors owned by the enterprises the gross savings of enterprises and income factors belonging to the state.

Considering the adopted definition of legal destructive entrepreneurship it is needed to perform the analysis of all the activities of an entrepreneurial character which are consistent with the law and have negative impact on the mentioned determinants of GDP.

\section{Results}

The first determinant (according to the expenditures approach) of calculating GDP is households consumption. It is linked to the income method because lower income means lower opportunities of expense.

Legal activities that have negative impact on these incomes and/or expenses include:

- services involving a reduction in disposable income of households, e.g. an increase in the cost of debt (foreign currency loans, the phenomenon of the spiral of debt among bank and shadow bank customers) and a reduction in savings through services designed to resemble safe bank deposits, or investments in shadow banks;

- services involving a reduction the number of households (e.g. agencies that offer or promote work abroad causing emigration);

- information services which could affect consumer behavior (e.g. information of an impending crisis could cause consumers to abstain from some of the planned purchases).

Loans in currencies other than that of the disposable income in many countries $^{1}$ caused the problem of mounting debt which was the result of the appre-

${ }^{1}$ Such a situation occurred in the following countries: Croatia, Spain, Austria, Poland, France, Germany, Hungary, Greece, Luxembourg, Holland and Italy (Brown et al., 2009, p. 4; PAP, 2015). 
ciation of the currency of the loan for example: CHF, EUR, USD. Admittedly, in short term following the granting of such loans an increase in expenses related to granted loans or credits can be expected, but the negative effects can be observed over a longer period, counted in years.

The same situation concerned the reduction of household savings which could be used for consumption. One of the best examples of this are the so-called 'polisolokaty' (policy deposits) offered in Poland by commercial banks. Despite the misleading name, these services were not deposits and resulted in the socalled. 'draining of the wallets of bank customers' reaching the scale of 50 billion PLN (Kołodziej, 2016). The tendency of nationals to leave the country is a result of a number of factors. One of them is the functioning of temporary employment agencies that help find better paying jobs abroad.

Another example of the negative impact on consumption are all kinds of services forming public opinion e.g. the media, influential position of companies such as e.g. credit rating agencies. Scaring the public with e.g. the coming financial crisis may result in a lower tendency of households to make purchases. This situation was described in the press (Czubkowska, 201la; 2011b) and even in the interpellation of the Minister of the Economy regarding the crisis (Sobecka, 2011). Krugman even said that it was the sharp drop in private spendings in indebted European countries which was the consequence of the crisis in the United States led these countries to economic crisis (PAP, 2011). A similar statement was expressed by the Commissioner for Internal Market and Services of the European Union, M. Bernier. He was considering a ban on state evaluations by rating agencies in the situation when these countries were in the process of negotiating financial assistance. According to many politicians, an assessment of credit rating agencies, who have the character of opinion leaders, contributed to the exacerbation of the economic crisis (Maciejewicz, 2011). Legal and destructive activities are also services aiming at misinformation, for example the transmission of false information or even obscuring the real situation. Examples of such services was the sale of swaps to Greece, by JP Morgan Chase and Goldman Sachs banks. The thus created derivative transactions were designed to hide the excessive deficit of Greece's budget in order to meet EU rules with relation to the Maastricht limit level (Balzli, 2010). As a result, these banks have made earnings on services that contributed to the economic crisis.

A further determinant of GDP is investment. In this case, it should also be connected with income and savings. Legitimate activities of destructive influence on the reduction of investments are:

- speculative services (speculations), affecting the reduction in income or even generating losses, depriving businesses of the possibility to purchase machinery, halls, etc.; foreign currency loans or leases should be included there as well, together with derivatives of speculative character, e.g. the so-called toxic options; 
- interference of an investor with foreign capital, which results in the cessation of the development of the domestic company or bringing it to bankruptcy or closure;

- services, the effect of which is to reduce the number of households, as this may result in lower interest in the purchase of new flats and houses, through which developers can opt out of local market;

- services involving a reduction in disposable income of households through an increase of the cost of debt and loss of creditworthiness, which are needed for the purchase of flats and houses;

- information services which could affect consumer behavior in connection with the purchase of a flat or a house.

Speculative transactions and therefore those that do not secure a particular risk, commonly called 'toxic options', resulted the loss of the amount of approx. 9 billion PLN in Polish companies. As a result of these losses, many companies declared bankruptcy (PAP, 2016). Loans and leases in foreign currency, in a situation of the weakening of the national currency, also led to the creation of higher financial expenses, reducing the income of companies and their ability to purchase.

Another example of legal destructive activity from the perspective of the investment is the intervention of a foreign investor. They could buy a domestic manufacturing company (or majority stake) in order to close it (or reduce its activities) getting rid of a local competitor in this way. Such an action reduces or even eliminates the expenses of the domestic company. One of the examples of such behaviour is the case of the purchase of the Polish company Prefabet by a Danish investor, and then closing 3 of its 5 production plants.

Another determinant of GDP are government expenses. Since the government can make decisions on an entrepreneurial character in relation to the state, reducing the spendings will reduce GDP, but also will improve its financial situation, e.g. reduce the budget deficit and/or debt. It should be noted that usually these expenses are not investments. Russia's budget for example depends largely on the prices of crude oil and natural gas. By increasing spendings on the construction of modern nuclear power plants in other countries, Russia has not only diversified the risks associated with these energy resources, but also provides a future income resulting just from this investment, not to mention the dependence of other economies on the price of the raw material sold. The actions of an entrepreneurial country may take other forms. They can be related, for example, with the exploration and reporting of claims (offensive action) or defense against such claims (defensive action).

An example of countries making claims against enterprises is a dispute between the US government and the company Volkswagen. As a result of the agreement, Volkswagen undertook a provision in the amount of 10 billion USD, to meet future civil actions of US citizens in connection with the so-called emissions scandal (Jber, 2016). The money is to be transferred to the carmaker's customers from the US, thus increasing their purchase ability. Actions taken by 
the European countries on the same issue ended in failure. As a result, payments will be charged to the European company, reducing its savings and investment opportunities, while supplying budgets of US households, increasing their income and consumption possibilities.

The reduction of a country's income from net tax may be associated with the so-called creative accounting which is in accordance with the law and results in avoidance or debasement of taxes paid by businesses.

A further determinant of GDP is net exports. Legitimate businesses' destructive behaviour in this aspect manifest by a decrease in the value of net exports by:

- a reduction in exports,

- an increase in imports.

Imported products replace the products manufactured by the domestic company.

When analyzing the above examples of legal destructive entrepreneurship, the question that should be asked is whether those examples are used only for the purpose of rent-seeking or rent-destroying. It is difficult to clearly include them in the frame of cited definition. This would require to detail:

- how to measure the influence on the economic environment or in the legal status;

- whether this influence would take place before, during or after actions that result in the acquisition of annuities;

- how to define the actions to characterise the acquisition or destroying of these rents.

None of the above-described examples refer directly to the legal status, except that they were all legal. It is also difficult to answer the question of how these examples might be involved (ex-ante or ex-post) with influencing the economic environment. The last question refers to the alternative from the definition of A. Krueger (1974) of using the conjunction 'or', which indicates that only one of the two accepted conditions can be met in order to complete an action for rent-seeking. Too general a definition of rent and rent-seeking do not allow the answer to that question.

\section{Conclusion}

Analysis of the available subject literature indicates a different approach to the notion of destructive entrepreneurship and a wide range of the proposed definitions. The attempts to define this term, taken so far, focused mainly on the phenomenon of exploration and elimination of rents, which in itself has not been precisely defined. This situation complicates the possibility of indicating behaviour that would be destructive in its consequences.

The current author's approach takes into account the current scientific achievements while also proposing a definition which makes it possible to an- 
alyse the activity that is legal and entrepreneurial and classify it as productive, unproductive or destructive.

According to the accepted definition, legal destructive entrepreneurship means a set of activities consistent with applicable laws which have negative net impact on the GDP of the countries where the situation is considered. Such activities generate benefits at the micro scale (regardless of whether they take place in the tested country or in another country), or the macro scale in another country. Unproductive entrepreneurship is an intermediate state between destructive and productive. The nature of unproductive activities means that the sum of the effects taken by the entity, positively and adversely affecting GDP are equilibrated.

On the basis of the adopted definition, research can be taken, not only to attempt to identify the scale of the phenomenon of an unproductive or destructive activities in the economy due to their attitude to the law, but also to undertake the debate on how to reduce this kind of activities.

\section{References}

Backhaus, J.G. (1997). Henry George's ingenious tax. American Journal of Economics and Sociology, 56(4). doi:10.1111/j.1536-7150.1997.tb02655.x.

Balzli, B. (2010). How Goldman Sachs helped Greece to mask its true debt. Retrieved 12.02.2017 from http://www.spiegel.de.

Baumol, W.J. (1990). Entrepreneurship: productive, unproductive, and destructive. Journal of Political Economy, 98(5).

Begg, D., Fisher, S., \& Dornbush, R. (1993). Ekonomia. Warszawa: PWE.

Brooke, G.T.F. (2010). Uncertainty, profit and entrepreneurial action. Journal of the History of Economics Thought, 32(2). doi:10.1017/S1053837210000179.

Brown, M., Peter, M., \& Wehrmüller, S. (2009). Swiss franc lending in Europe. Aussenwirtschaft, 64(2).

Chołaj, H. (1966). Cena ziemi w rachunku ekonomicznym. Warszawa: PWE.

Coyne, Ch.J. \& Leeson, P.T. (2004). The plight of underdeveloped countries. Cato Journal, 24(3).

Czakon, W. (2010). Zasobowa teoria firmy w krzywym zwierciadle. Przegląd Organizacji, 4.

Czubkowska, S. (201la). Boimy się kryzysu i na wszelki wypadek przestajemy kupować. Retrieved 12.02.2017 from http:/ /biznes.gazetaprawna.pl.

Czubkowska, S. (2011b). Kryzys po polsku. Zaciskamy pasa. Retrieved 12.02.2017 from http://forsal.pl.

Czyżewski, A., \& Czyżewski, B. (2015). Ziemia i jej renty w nowym paradygmacie rozwoju rolnictwa. In A. Czyżewski, \& B. Klepacki (Eds.). Problemy rozwoju rolnictwa i gospodarki żywnościowej w pierwszej dekadzie cztonkostwa Polski w UE. Warszawa: PTE.

Czyżewski, B. (2010). Kontrowersje wokół rent gruntowych: od ekonomii klasycznej do czasów współczesnych. Ekonomista, 2. 
Desai, S., \& Acs, Z.J. (2008). A theory of destructive entrepreneurship. Jena Economic Research Paper, 2007-085. doi:10.2139/ssrn.1029648.

Douhan, R., \& Henrekson, M. (2008). Productive and destructive entrepreneurship in a political economy framework. IFN Working Paper, 761.

George, H. (2009). Progress and poverty. Cambridge: Cambridge University Press. doi:10.1017/CBO9780511693687.

Henrekson, M. (2007). Entrepreneurship and institutions. IFN Working Paper, 707.

Jber. (2016). Feralne silniki VW. Koncern wyptaci po 5 tys. dol. odszkodowania wtaścicielom aut $z$ USA. Retrieved 12.02.2017 from http:/ / www.money.pl.

Kołodziej, A. (2016). Polisolokaty to problem wart 50 mld zt. PiS zapowiada uwolnienie z niewoli. Retrieved 12.02.2017 from http://www.money.pl.

Krueger, A.O. (1974). The political economy of the rent-seeking society. American Economic Review, 64(3).

Maciejewicz, P. (2011). Moody's ostrzega Polskę. Gazeta Wyborcza, 21.10.2011.

Marks, K. (1959). Kapitat. vol. II and III. Warszawa: Książka i wiedza.

Murphy, M., Shleifer, A., \& Vishny, R.W. (1991). The allocation of talent: implications for growth. Quarterly Journal of Economics, 106(2). doi:10.2307/2937945.

PAP. (2011). Noblista zna prawdziwa przyczynę kryzysu. To nie nadmierne wydatki. Retrieved 12.02.2017 from http://gospodarka.dziennik.pl.

PAP. (2015). Najwięcej kredytów w szwajcarskich frankach mają Austriacy. Retrieved 12.02.2016 from http:/ / wyborcza.biz.

PAP. (2016). Szatamacha: straty wskutek toksycznych opcji walutowych - 9 mld zt. Retrieved 12.02.2017 from http://www.parkiet.com.

Pareto, V. (1964). Cours D'economie Politique, 2. Geneve: Librairie Droz. doi:10.3917/droz.paret.1964.01.

Robinson, J. (1948). Economics of imperfect competition. London: Palgrave Macmillan. doi:10.1007/978-1-349-15320-6.

Samuelson, P.A. (1951). Economics. New York: McGraw-Hill.

Sauka, A. (2008). Productive, unproductive and destructive entrepreneurship: a theoretical and empirical exploration. Wiliam Davidson Institute Working Paper, 917.

Sautet, F. (2005). The role of institutions in entrepreneurship: implications for development policy. George Mason University. Mercatus Policy Primer, 1.

Smith, A. (1954). Badania nad naturą i przyczynami bogactwa narodów. Warszawa: PWN.

Sobecka, E. (2011). Interpelacja nr 504 do ministra gospodarki w sprawie kryzysu gospodarczego. Retrieved 12.02.2017 from http://www.sejm.gov.pl.

Starnawska, M. (2011). Przedsiębiorczość w kontekście otoczenia instytucjonalnego - refleksje. Master of Business Administration, 1(108). 


\section{Acknowledgements}

Author contributions: author has given an approval to the final version of the article.

Funding: this research was fully funded by the Gdańsk University of Technology. 


\section{Appendix}

Scheme 1 .

Graphic representation of the differences between productive, unproductive and destructive entrepreneurship

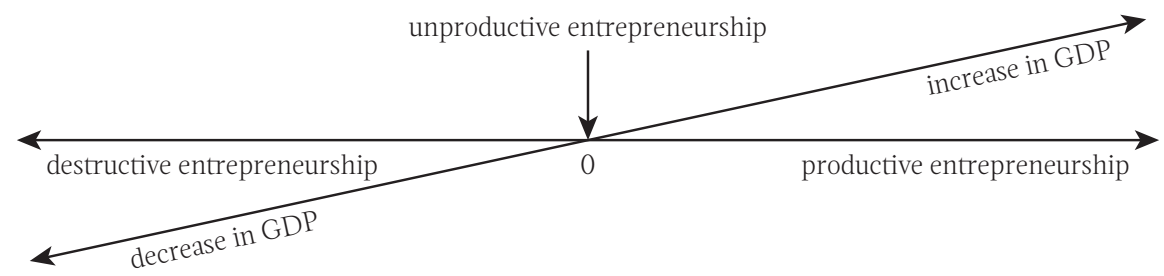

Source: Own preparation.

Scheme 2.

The typology of legal and illegal entrepreneurship

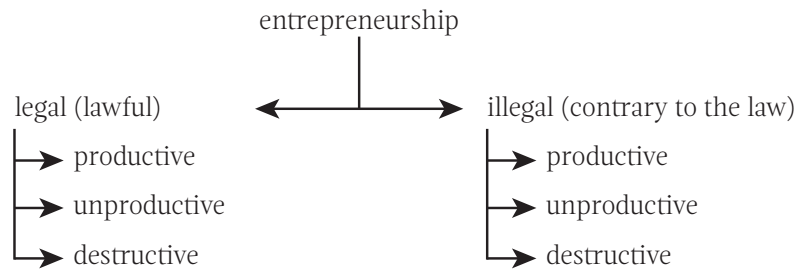

Source: Own preparation. 